\title{
Analisis Dampak Kebijakan Pembatasan Waktu Operasional Pasar Di Kabupaten Minahasa Akibat Penanggulangan Covid-19
}

\author{
Sangputri Sidik ${ }^{1)}$, Awaluddin Hasrin ${ }^{2)}$, Siti Fathimah ${ }^{3)}$ \\ ${ }^{123}$ Fakultas Ilmu Sosial, Universitas Negeri Manado \\ Email: putrisidik@unima.ac.id ${ }^{1}$, awaluddin@unima.ac.id ${ }^{2}, \underline{\text { sitifathimah@unima.ac.id }^{3}}$
}

\begin{abstract}
Abstrak. Penelitian ini mencoba untuk menganalisis dampak sosial dan ekonomi yang dialami masyarakat utamanya pada pedagang di pasar Tondano Kabupaten Minahasa setelah penetapan kebijakan pembatasan masa operasional pasar Tondano akibat pencegahan penyebaran wabah COVID-19. Metode yang digunakan dalam penelitian ini adalah deskriptif kualitatif. Informan kunci dalam penelitian ini adalah para pedagang di pasar Tondano Kabupaten Minahasa. Dengan teknik pengumpalan data, reduksi data, penyajian data dan penarikan kesimpulan. Hasil penelitian ini menunjukan bahwa dampak yang timbul akibat penetapan kebijakan pembatasan operasional pasar di tondano antara lain dampak ekonomi berupa penurunan omset dagangan serta rasa cemas akan penularan Covid-19 saat melakukan transaksi
\end{abstract}

Kata kunci: Dampak Sosial Ekonomi, Pasar, Covid-19

Abstract. This study tries to analyze the social and economic impacts experienced by the community primarily on traders in the Tondano market in Minahasa Regency after the establishment of the Tondano market operational restriction policy due to the prevention of the spread of the COVID-19 outbreak. The method used in this research is descriptive qualitative. The key informants in this study were traders in the Tondano market in Minahasa Regency. With data mixing techniques, data reduction, data presentation and conclusion drawing. The results of this study indicate that the impacts arising from the establishment of market operational restriction policies in tondano include economic impacts in the form of reduced merchandise turnover and anxiety over the transmission of Covid-19 when conducting transactions.

Keywords: social and economic, market, covid-19

\section{PENDAHULUAN}

Akhir tahun 2019, sebuah virus baru ditemukan di Wuhan Provinsi Hubei, China. Belakangan penemuan virus ini dikaitkan dengan adanya sebuah pasar yang memperjualbelikan hewan liar yang dianggap bisa menyebarkan virus ketika dikonsumsi. Awalnya virus ini di kenal dengan nama 2019 novel (2019-nCoV), kemudian pada 11 Februari 2020 WHO mengumumkan Coronavirus Disease (COVID-19) sebagai nama baru pada penyakit itu. Dari kota Wuhan COVID-19 menyebar antar manusia hingga kemudian menyebar ke seluruh dunia, tak terkecuali Indonesia yang terkena dampak langsung pandemik COVID-19. Pada pada akhirnya, WHO mengumumkan COVID-19 telah menjadi pandemick (Susilo, et al., 2020). Di Indonesia COVID-19 pertama dilaporkan awal Maret 2020 dengan dua kasus. Data 1 Mei 2020 menunjukkan bahwa terdapat sejumlah 10.551 kasus positif, sejumlah 1.591 sembuh dan 800 angka kematian. Hingga saat ini perkembangan penularan COVID-19 masih terbilang tinggi di seluruh dunia.

Upaya pemerintah Indonesia dalam mengantisipasi dan mengurangi jumlah penderita virus corona telah dilakukan. Mulai dari pemerintah pusat hingga pemerintah daerah termasuk di tingkatan paling rendah RT/RW. Berbagai kebijakan telah digagas sebagai upaya mencegah diantaranya dengan pelaksanaan kebijakan pembatasan aktifitas keluar rumah, bekerja dari rumah (work from home), kegiatan sekolah dirumahkan dengan melakukan belajar dari rumah, aktivitas peribadatan juga dilakukan dari rumah. 
Di beberapa daerah yang masuk dalam zona merah telah malakukan kebijakan PSBB (Pembatasan Sosial Bersekala Besar) seperti Jakarta. Jakarta yang merupakan ibu kota negara yang juga merupakan wilayah di Indonesia dengan kasus terbesar dengan jumlah kasus positif 4.317 kasus.

Pemerintah telah memberlakukan kebijakan PSBB melalui Peraturan Pemerintah Nomor 21 Tahun 2020 yang dipertegas pada Peraturan Menteri Kesehatan (PERMENKES) RI Nomor 9 Tahun 2020 Tentang Pedoman Pembatasan Sosial Berskala Besar. Namun sebelum itu terkait perkembangan virus corona tersebut, sejak awal pemerintah telah membuat kebijakan sebagai langkah pertama yaitu berupa anjuran social distancing. Data persebaran COVID-19 di Indonesia dapat di lihat dari indografis berikut ini.

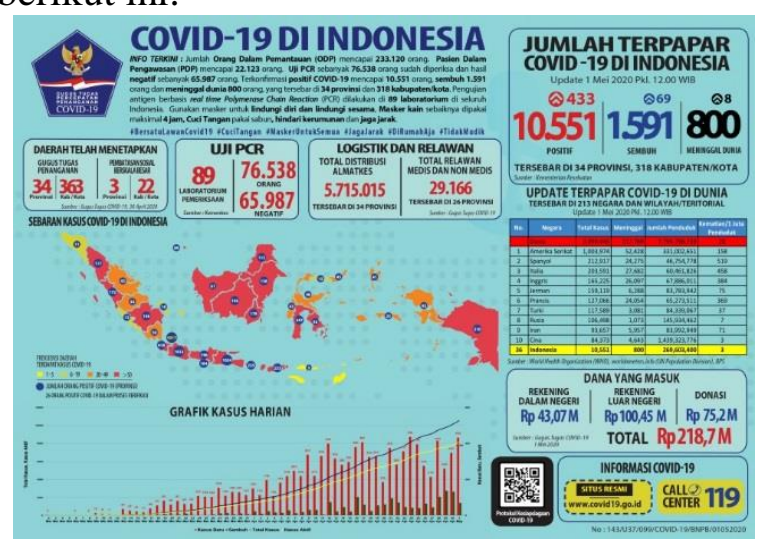

Gambar 1. Indografis Covid-19 di Indonesia (COVID-19, 2020)

Pemerintah memahami betul jika penyebaran dari COVID-19 bisa melalui percikan lendir kecil-kecil dari dinding saluran pernapasan seseorang yang dikeluarkan pada saat orang itu sedang batuk dan bersin. Karena itu, pemerintah menganjurkan kepada siapapun yang batuk dan yang menderita penyakit influenza sedapat mungkin mengenakan masker, guna membatasi percikan droplet dari yang orang bersangkutan. Selain itu dengan aturan menjaga jarak antar orang, agar memumgkinkan potensi tertular penyakit bisa diminimalisir. Dengan demikian kegiatankegiatan yang mengumpulkan orang dengan jumlah yang besar harus dihindari. Setiap komponen masyarakat harus memiliki kesadaran bersama untuk menaati himbauan untuk menunda melaksanakan kegiatan yang akan mengumpulkan orang dalam jumlah besar yang dapat menyebabkan kerumunan.

Oleh karena itu, phisical distancing harus diterapkan pada setiap aktivitas kita, baik di tempat kerja ataupun di lingkungan rumah tangga. Dan juga harus melaksanakan pola hidup sehat dan bersih sebagai bentuk pencegahan dini dengan selalu melakukan aktivitas cuci tangan menggunakan sabun dengan air yang mengalir. Baik setelah beraktivitas maupun sebelum.

Perkembangan kasus COVID-19 di Indonesia sampai pada tahap yang cukup mengkhawatirkan, hingga semua daerah mempersiapkan kebijakan tersendiri sebagai upaya penangan dan pencegahan penyebaran COVID-19. Termasuk di kabupaten Minahasa, melalui surat edaran Bupati nomor nomor 265/BM-111-2020 tentang jadwal operasional pasar di Minahasa (sulutpos.com, 2020).

Kebijakan ini dilakukan sebagai upaya pemerintah kabupaten Minahasa untuk mencegah penyebaran COVID-19. Sebab diketahui pasar merupakan salah satu titik kumpul seluruh masyarakat, dalam melakukan aktivitas jual beli setiap harinya. Di pasar orang-orang tentunya akan bersentuhan secara langsung dengan orang lain. Sementara himbauan pemerintah untuk menerapkan gaya hidup membatasi jaraak dengan orang lain. Utamanya di tempattempat umum. Pasar tondano merupakan pasar terletak di Ibu Kota Kabupaten, pasar ini merupakan pusat perdagang di kabupatan Minahasa.

Dalam situasi yang mendesak akibat penyebaran virus COVID - 19 pemerintah daerah tentunya akan menetapkan suatu kebijakan, yang dipandang dapat mencegah penularan virus COVID-19. Kebijakan publik pada umumnya merupakan suatu hal yang dilakukan oleh pemerintah yang bertujuan tertentu demi kepentingan seluruh seluruh lapisan masyarakat. Suatu kebijakan publik ditetapkan oleh suatu badan atau aparat pemerintah. Proses pengusunan kebijakan harus terdapat di dalamnya diawali input, proses dan output. Isu tentang kebijakan 
pemerintah adalah proses input, sedangkan proses kebijakan adalaah pengusunan rumusan formulasi kebijakan serta implementasi dari kebijakan. Sementara di bagian akhir suatu proses kebijakan adalah kinerja kebijakan yang merupakan output proses kebijakan publik.

Dalam hal kebijakan birokrasi, Max Weber menjelaskan tentang betapa pentingnya legitimasi dalam suatu kebijakan. Suatu kebijakan yang berimplikasi pada tata tertib sosial, dapat dilaksanakan jika suatu masyarakat mengikuti aturan yang berlaku, sesuai dengan aturan-aturan yang berlaku. Aturan-aturan inilah yang mampu menjadi acuan dalam masyarakat saat ini. Terdapat suatu kesepakatan bersama tentang bagaimana merumuskan dan menegakkan peraturan-peraturan dan hak-hak yang mesti dilindungi. Dan juga kewajiban-kewajiban yang harus dilaksanakan setiap masyarakat. Dengan demikian suatu kebijakan dapat melegitimasi dan berlaku bagi aturan dan seluruh aspek-aspek sosial yang ada. Dalam perumusan kebijakan setidaknya ada tiga belas model perumusan kebijakan, pertama adalah Model Strategis.

Model Strategis menggunakan formula tuntutan perumusan strategi sebagai basis perumusan kebijakan. Menurut (Nugroho, 2012) perencanaan strategis lebih memfokuskan pada pengidentifikasian dan pemecahan isu-isu. Model ini merupakan salah satu derivat manajemen dari model rasional karena mengandaikan bahwa proses perumusan kebijakan adalah proses rasional dengan pembedaan bahwa model ini lebih fokus pada rincian-rincian langkah manajemen.

Menurutnya penerapan dari suatu kebijakan pada prinsipnya adalah cara agar suatu kebijakan dapat mencapai tujuan sebagaimana yang telah ditetapkan. Suatu kebijakan dipandang lebih baik jika dimaknai sebagai proses administratif untuk mengeksekusi keputusan-keputusan politis dengan mendayagunakan serangkaian instrumen kebijakan untuk menghasilkan perubahan sosial ke arah yang dikehendaki, yang mencakup pula serangkaian proses negosiasi antara implementor dengan sasaran kebijakan untuk memastikan tercapainya misi kebijakan. Selain itu dibutuhkan kolaborasi antara pemerintah dan warga masyarakat yaitu melalui konsultatif dan kemitraan agar setiap kebijakan dapat diukur dampak sosial dan ekonominya (Yasintha, 2020)

Dari uraian di atas, penelitian ini akan berupaaya menjawab bagaimana dampak sosial dari kebijakan pembatasan waktu operasional pasar di kabupaten Minahasa khususnya di pasar Tondano. Penelitian ini akan di fokuskan pada masyarakat yang terkena dampak secara langsung utamanya para pedagang yang ada di pasar Tondano. Penentuan pasar Tondano sebagai lokasi penelitian dengan melihat aspek bahwa pasar Tondano merupakan pasar yang berada di pusat kota ibu kota kabupaten Tondano.

\section{KAJIAN LITERATUR}

\section{a. Konsep Dasar Perubahan Sosial}

Perubahan merupakan gejala gejala yang selalu melekat pada setiap masyarakat pada setiap aspek kehidupan. Pada masyarakat terjadi perubahan struktur, organisasi, serta hubungan sosial yang dapat disebabkan oleh berbagai penyebab. Misalnya modernisasi atau industrialisasi. Namun perubahan sosial tidak hanya berada pada kontesk itu, karena banyak pula perubahan yang disebabkan oleh pemahaman sosial mengenai sesuatu, sumber nilai yang menjadi rujukan tingkah laku, interaksi.

Perubahan sosial menurut pandangan Wilbert Moore (1987) sebagai perubahan struktur sosial, pola perilaku dan interaksi sosial. Sehingga setiap perubahan yang terjadi pada struktur masyarakat disebut sebagai perubahan sosial. (Soekanto, 1984). Ruang lingkup perubahan perubahan sosial mencakup unsur-unsur kebudayaan material dan inmaterial dengan menekankan pengaruh yang besar dari unsur-unsur inmaterial. Sehingga dengan begitu, perubahan sosial terjadi dalam fungsi dan struktur masyarakat.

Perubahan sosial merupakan perubahan dalam hubungan sosial (social relationship) atau perubahan terhadap keseimbangan (equilibrium) hubungan sosial tersebut (Muhtadi, 2016). 
Suatu perubahan sosial tidak dapat dilihat hanya dari satu sisi, karena suatu perubahan akan berdampak kepada sektor-sektor yang lain. Gejalanya dapat dilihat dari sistem nilai dan norma yang pada suatu saat berlaku akan tetapi disaat yang lain tidak berlaku atau suatu peradaban yang sudah tidak sesuai dengan dengan peradaban masa kini. Namun demikian, perubahan sosial juga tidak hanya berimplikasi pada suatu kemajuan, tatepi dapat pula berarti kemunduran. Meskipun dinamika sosial selalu di araahkan pada suatu gejala transformasi yang bersifat linier.

Tekanan pada lembaga-lembaga kemasyarakatan sebagai suatu himpunan pokok manusia di mana perubahan-perubahan tersebut memengaruhi segi-segi yang lain dalam struktur masyarakat. Hal ini sangat berkaitan asal mula perubahan sosial itu. Di mana perubahan sosial ada yang di rencanakan yaitu melalui program pembangunan dan perubahan sosial yang tidak direncakan seperti bencana alam atau peperangan (Setiadi \& Kolip, 2011).

\section{b. Perubahan Sosial Merupakan Awal Mula Munculnya Teori Tentang Dampak Sosial dan Ekonomi.}

Teori Teori perubahan sosial sebagaai awal mula munculnya teori tentang dampak sosial dan ekonomi. Perubahan sosial menurut Wilryohandoyo adalah bentuk peradaban manusia akibat adanya perubahan alam, biologi, fisik yang terjadi sepanjang kehidupan manusia. Adapaun menurut Kingslay Davis, perubahan sosial merupakan perubahan yang terjadi di dalam struktur dan fungsi masyarakat.

Menurut selo soemardjan, perubahan sosial adalah segala perubahan pada lembaga kamasyarakatan dlam suatu masyarakat yang memengaruhi sistem sosialnya, termasuk di dalamnya nilai, sikap, dan pola perilaku di antaranya kelompok-kelompok dalam masyarakat. Selanjutnya menurut George ritzer menjelaskan tentang analisis kebijakan sosial dengan beberapa indicator, seperti:

- Perubahan sistem sosial;

- Nilai-nilai individu dan kolektif

- Perilaku hubungan sosial

- Gaya hidup dan ekspresi mode
- Struktur masyarakat.

\section{c. Konsep Dasar Dampak Sosial}

Kata dampak dalam kamus Bahasa indonesia adalah benturan, pengaruh yang mendatangkan akibat, baik positif maupun negative. Pengaruh adalah daya yang ada dan timbul dari sesuatu (orang, benda) yang ikut memberi watak, kepercayaan atau perbuatan seseorang. Pengaruh adalah suatu keadaan yang di dalamnya terdapat hubungan sebab akibat antara yang memengaruhi dengan yang dipengaruhi.

Defenisi lain dampak sosial adalah suatu bentuk akibat atau pengaruh yang terjadi karena adanya sesuatu hal. Pengaruh yang dimaksud adalah akibat yang terjadi pada masyarakat karena suatu kejadian itu memengaruhi masyarakat atau hal lainnya di dalam masyarakat. Menurut surto haryono, dampak dibagi menjadi dua yaitu dampak primer dan dampak sekunder. Dampak primer adalah dampak langsung yang dirasakan oleh suatu kegiatan, sedangkan dampak sekunder tidak langsung dirasakan oleh suatu kegiatan (Ridwan, M.Ag, 2019).

\section{METODE PENELITIAN}

Penelitian ini merupakan jenis penelitian kualitatif yaitu penelitian yang memberikan penjelasan tentang dampak sosial ekonomi pada kebijakan pembatasan operasioanl pasar Tondano Kabupaten Minahasa Sebagai upaya penanggulangan penyebaran COVID-19.

Penelitian kualitatif merupakan penelitian yang mendeskripsikan dan menganalisis makna yang terkandung dibaliknya fenomena sebagai makna yang tersembunyi, atau dengan sengaja disembunyikan sehingga menghasilkan data deskriptif dalam bentuk kata-kata, baik tertulis maupun (Sugiono, 2017).

Penelitian ini dilakukan di pasar kabupaten Minahasa provinsi Sulawesi Utara Lokasi ini dipilih sebagai tempat mengumpulkan data karena penetapan kebijakan ini berdampak langsung pada semua pasar yang berada di kabupaten Minahasa. Fokus penelitian ini adalah untuk menjelaskan dampak sosial dan ekonomi pada kebijakan pembatasan waktu operasional pasar Tondano Kabupaten Minahasa sebagai 
bentuk penanggulangan penyebaran Covid-19 di kabupaaten Minahasa.

Teknik pengumpulan data dalam penelitian ini dilakukan dengan metode yaitu pengamatan (observasi) merupakan metode pengumpulan data yang digunakan untuk menghimpun data penelitian melalui pengamatan, awancara (interview) merupakan percakapan dengan maksud tertentu yaitu dengan wawancara bebas dan mendalam, dan dokumentasi merupakan pengumppulan data sekunder melalui pengambilan gambar di lokasi berupa dokumen atau foto. Proses analisis dalam penelitian kualitatif, secara khusus kegiatannya dilakukan secara induktif, interaksi dari setiap unit datanya, bersamaan dengan proses pelaksanaan pengumpulan data, dan dengan proses siklus (Miles \& Huberman, 2014).

Empat komponen utama analisis tersebut adalah pengumpulan data, reduksi data, sajian data, penarikan kesimpulan. Menguji keabsahan data penelitian menggunakan metode Trianggulasi, yaitu pemeriksaan keabsahan data yang memanfaatkan sesuatu yang lain di luar data untuk keperluan pengecekan atau sebagai pembanding terhadap data tersebut, dan teknik trianggulasi yang paling banyak digunakan adalah dengan pemeriksaan melalui sumber yang lainnya.

\section{HASIL DAN PEMBAHASAN}

\section{d. Dampak Sosial}

Aktivitas jual beli tidak lagi berlangsung seperti sebelum masa pandemi Covid-19. Para pedagang dan pembeli dihantui rasa khawatir tertular covid-19 saat melakukan transaksi jual beli. Orang-orang mesti menjaga jarak dengan orang lain. Terutama mengikuti himbauan pemerintah tentang Phisical Distansing saat melakukan aktivitas di luar rumah. Masyarakat harus mengikuti setiap protokol kesehatan yang telah diatur. Phisical Distancing secara umum merupakan pembatasan kontak fisik, ini adalah upaya untuk mengendalikan proses penyebaran covid 19. Dengan mengurangi kontak fisik secara langsung maka dimungkinkan akan meminimalisir terjadinya penularan penyakit yang dapat berakibat pada kemaatian (Yunus \& Rezki, 2020).

\section{e. Dampak Ekonomi}

Kebijakan tentang pembatasan waktu operasional pasar di kabupaten minahasa berdampak langsung bagi para pedagang yang kehidupan sehari-harinya sebagai pedagang di pasar-pasar yang ada di kabupaten minahasa. Secara umum para pedagang yang berada di pasar-pasar di kabupaten minahasa merupakan pelaku usaha micro yang menggantungkan kehidupannya dari usaha jual beli di pasar.

Sejak awal penetapan kebijakan pembatasan waktu operasional pasar di kabupaten Minahasa, para pedagang melakukan penolakan terhadap kebijakan itu. Meskipun secara resmi pemerintah telah menetapkan melalui surat edaran namun dilapangan terjadi penolakan dengan tidak mengindahkan aturan yang telah ditetapkan. Aktivitas jual beli tetap berlangsung di pasar tanpa rasa khawatir penyebaran virus covid19.

Kekhawatiran akan menurunnya penghasilan menjadi faktor utamanya. Di tengah situasi itu pemerintah mempertegas aturan dengan menurunkan aparan keamanan untuk menertipkan pelaku yang masih menggelar dagangannya ditengah maraknya penyebaran virus covid-19. Meja-meja atau lapak pedagang dibongkar secara paksa dan disita oleh petugas. Dengan begitu para pedagang harus tunduk pada aturan yang ada dengan konsekuensi. Berkurangnya penghasilan yang mereka terima atau bahkan merugi.

Stok barang dagangan menumpuk tidak dapat dijual, terutama buah-buahan dan sayur mayur serta hasil bumi lainnya yang menjadi komoditi andalan para pedagang di Kabupaten Minahasa. Diketahui kabupaten minahasa merupakan kabupaten penghasil buah dan sayur-sayuran. Buah dan sayuran yang ada di kabupaten minahasa sangat melimpah sehingga dengan adanya pembatasan tersebut menjadi terkendala untuk dipasarkan.

Dengan begitu dapat dipastikan kerugian para pedagang yang terkena dampak dari kebijakan pembatasan tersebut. Meskipun demikian para pedagang tetap berupaya untuk 
memasarkan produk dagangan yang mereka miliki dengan menggelar lapar di pinggiran jalan. Pasar tumpah merupakan alternatif yang dilakukan para pedagang dengan menggelar aktivitas jual beli yang tempat yang berbeda-beda yang tidak lagi terkosentrasi di dalam pasar.

Umumnya barang dagang dipajang di lapak-lapak seadanya yang tidak permanen. Kegiatan ini dilakukan sebagai upaya untuk meminimalisir kerugian, sebab sebagai besar pedagang kecil yang ada sangat menggantungkan kehidupannya dari aktivitas jual beli di pasar. Secara umum pelaku Usaha Mikro, Kecil, dan Menengah (UMKM) merupakan suatu sektor penting dalam perekonomian Indonesia. Ketika sektor ini terkena dampak pada penurunan produksi dan nilai perdagangan maka akan berimbas pada jumlah tenaga kerja yang harus kehilangan pekerjaannya karena pandemi ini (Pakpahan, 2020).

\section{f. Analisis Dampak Penetapan Kebijakan Pembatasan Waktu Operasional Pasar Di Kabupaten Minahasa.}

Perubahan merupakan gejala yang selalu melekat pada setiap masyarakat pada setiap aspek kehidupan. Pada masyarakat terjadi perubahan struktur, organisasi, serta hubungan sosial yang dapat disebabkan oleh berbagai penyebab. Misalnya modernisasi atau industrialisasi. Namun perubahan sosial tidak hanya berada pada kontesk itu, karena banyak pula perubahan yang disebabkan oleh pemahaman sosial mengenai sesuatu, sumber nilai yang menjadi rujukan tingkah laku, interaksi. Perubahan sosial menurut pandangan Wilbert Moore (1987) sebagai perubahan struktur sosial, pola perilaku dan interaksi sosial. Sehingga setiap perubahan yang terjadi pada struktur masyarakat disebut sebagai perubahan sosial. (Soekanto, 1984).

Ruang lingkup perubahan perubahan sosial mencakup unsur-unsur kebudayaan material dan inmaterial dengan menekankan pengaruh yang besar dari unsur-unsur inmaterial. Sehingga dengan begitu, perubahan sosial terjadi dalam fungsi dan struktur masyarakat. Perubahan sosial merupakan perubahan dalam hubungan sosial (social relationship) atau perubahan terhadap keseimbangan (equilibrium) hubungan sosial tersebut (Muhtadi, 2016)

Suatu perubahan sosial tidak dapat dilihat hanya dari satu sisi, karena suatu perubahan akan berdampak kepada sektor-sektor yang lain. Gejalanya dapat dilihat dari sistem nilai dan norma yang pada suatu saat berlaku akan tetapi disaat yang lain tidak berlaku atau suatu peradaban yang sudah tidak sesuai dengan dengan peradaban masa kini. Namun demikian, perubahan sosial juga tidak hanya berimplikasi pada suatu kemajuan, tatepi dapat pula berarti kemunduran. Meskipun dinamika sosial selalu di araahkan pada suatu gejala transformasi yang bersifat linier. Tekanan pada lembaga-lembaga kemasyarakatan sebagai suatu himpunan pokok manusia di mana perubahan-perubahan tersebut memengaruhi segi-segi yang lain dalam struktur masyarakat. Hal ini sangat berkaitan asal mula perubahan sosial itu. Di mana perubahan sosial ada yang di rencanakan yaitu melalui program pembangunan dan perubahan sosial yang tidak direncakan seperti bencana alam atau peperangan (Setiadi \& Kolip, 2011).

Bencana Pandemik COVID-19 telah merubah banyak aspek dalam kehidupan masyarakat global, temasuk indonesia. Dalam situasi yang pandemik setiap kebijakan pemerintah diharapakan dapat menekan atau memutus rantai penularan virus COVID-19 secara maksimal. Pemerintah kabupaten Minahasa turut andil dalam upaya penanggulangan penyebaran COVID-19 dengan menetapkan kebijakan - kebijakan yang dianggap efektif. Salah satunya adalah pembatasan waktu operasional pasar yang ada di Kabupaten Minahasa. Pasar tondano merupakan pasar yang berada di pusat ibu kota Minahasa.

Segala aktivis ekonomi masyarakat kota tondano berlangsung disini. Dengan diberlakukannya kebijakan pembatasan waktu operasional pasar tentu saja berdampak langsung kepada masyarakat. Terutama para pelaku ekonomi yang berada di pasar tersebut.

Secara sederhana dampak dapat dikatakan adalah sesuatu yang timbul akibat adanya 
Mei 2, 2020, from covid19.go.id:

suatu kejadian. Dampak juga bisa merupakan proses lanjutan dari sebuah pelaksanaan internal. Sosial diartikan sebagai sesuatu yang timbul dari adanya hubungan interaksi antar individu dengan individu lainnya dalam hal ini masyarakat. Dampak sosial adalah sebuah bentuk akibat atau pengaruh yang terjadi karena adanya sesuatu hal pengaruh yang dimaksud adalah akibat yang terjadi pada masyarakat, baik karena suatu kejadian itu mempengaruhi masyarakat atau hal lainnya didalam masyarakat. Analisa dampak sosial adalah suatu kajian yang dilakukan terhadap kondisi sosial, ekonomi, dan budaya masyarakat sebagai akibat dari pelaksanaan suatu kegiatan pembangunan di suatu wilayah atau area. Kajian dilakukan untuk menelaah dan menganalisa berbagai dampak yang terjadi baik positif maupun negatif dari setiap tahapan kegiatan mulai dari tahap pra konstruksi, konstruksi, sampai tahap operasi.

\section{KESIMPULAN}

Bencana Pandemik COVID-19 telah merubah banyak aspek dalam kehidupan masyarakat global, temasuk indonesia. Dalam situasi yang pandemik setiap kebijakan pemerintah diharapakan dapat menekan atau memutus rantai penularan virus COVID-19 secara maksimal. Pemerintah kabupaten Minahasa mesti turut andil dalam upaya penanggulangan penyebaran COVID-19 dengan menetapkan kebijakan - kebijakan yang proaktif terhadap masyarakat.

Pembatasan waktu operasional pasar yang ada di Kabupaten Minahasa tentu saja berdampak langsung kepada masyarakat. Terutama para pelaku ekonomi yang berada di pasar tersebut. Pemerintah juga mesti memikirkan jaring pengaman bagi masyarakat yang terkena dampak secara langsung, baik itu berupa permodalan usaha bagi pedagang ataupun kepastian keamanan bagi mereka saat melakukan aktivitas jual beli. Namun dalam situasi yang dilematis, diharapakan semua pihak dapan memahami situasi krisis ini baik itu pemerintah maupun masyarakat pada umumnya.

\section{DAFTAR PUSTAKA}

COVID-19, G. T. (2020, Mei 1). Indografis COVID-19 (1 Mei 2020). Retrieved

https://covid19.go.id/p/berita/infografi s-covid-19-1-mei-2020

Miles, M. B., \& Huberman, M. B. (2014). Analisis Data Kualitatif : Buku Sumber Tentang Metode - Metode Baru. Jakarta: UI-Press.

Muhtadi, S. A. (2016). Persfektif Perubahan Sosial. Bandung: Pustaka Setia.

Nugroho, R. (2012). Public Policy: Dinamika Kebijakan, Analisis Kebijakan, Manajemen Kebijakan. Jakarta: PT. Elex Media Komputindo.

Pakpahan, A. K. (2020). Covid-19 Dan Implikasi Bagi Usaha Micro, Kecil, Dan Menengah. Jurnal Ilmiah Hubungan Internasional(Edisi Khusus), 59-64.

Ridwan, M.Ag, D. (2019). Sosiologi Industri, Transformasi Menuju Masyarakat Post-Industri. Bandung: CV. Pustaka Setia.

Setiadi, E. M., \& Kolip, U. (2011). Pengantar Sosiologi, Pemahaman Fakta Dan Gejala Permasalahan Sosial; Teori, Aplikasi, Dan Pemecahannya. Jakarta: Kencana.

Soekanto, S. (1984). Teori Sosiologi Tentang Perubahan Sosial. Jakarta: Ghalia Indonesia.

Sugiono. (2017). Metode Penelitian Kuantitatif, Kuliatatif dan $R \& D$. Bandung: Alfabeta.

sulutpos.com. (2020, Mei 5). Retrieved from https://sulutpos.com/2020/03/pemkabminahasa-resmi-batasi-aktivitas-jualbeli-pasar-tradisional.html

Susilo, A., Rumende, C. M., Pitoyo, C. W., Santoso, W. D., Yulianti, M., Herikurniawan, . . . Yunihastuti, E. (2020). Coronavirus Disease 2019: Tinjauan Literatur Terkini. Jurnal Penyakit Dalam Indonesia, 7.1, 45-67. 
Yasintha, P. N. (2020). Collaborative Governance Dalam Kebijakan Pembangunan Pariwisata Di Kabupaten Gianyar. Jurnal Ilmiah Dinamika Sosial, 4.1, 1-23.

Yunus, N. R., \& Rezki, A. (2020). Kebijakan Pemberlakuan Lockdown Sebagai Antsipasi Penyebaran Corona Virus Covid-19. SALAM; Jurnal Sosial \& Budaya Syar-i, 227-238.

Yusup, D. K., Badriyah, M., Suyandi, D., \& Asih, V. S. (2020). Pengaruh Bencana Covid-19, Pembatasan Sosial, dan Sistem Pemasaran Online Terhadap Perubahan Perilaku Konsumen Dalam Membeli Produk Retail. http://digilib.uinsgd.ac.id, 1-10. 